\title{
Factors associated with poor asthma control in children aged five to 13 years
}

\author{
SL McGhan RN MN CAE ${ }^{1,2}, C$ MacDonald $\mathrm{MD}^{3}$, DE James $\mathrm{PhD}^{4}, \mathrm{P}$ Naidu MD ${ }^{1}, \mathrm{E}$ Wong $\mathrm{MD}^{5}$, \\ H Sharpe RN MN CAE ${ }^{1,5}$, PA Hessel PhD ${ }^{1,6,7}, A D$ Befus PhD ${ }^{1,5,8}$
}

\begin{abstract}
SL McGhan, C MacDonald, DE James, et al. Factors associated with poor asthma control in children aged five to 13 years. Can Respir J 2006;13(1):23-29.
\end{abstract}

BACKGROUND: Most children with asthma should be able to achieve acceptable control. However, are there differences between those with acceptable and poor control, and if so, how can health care approaches be modified accordingly?

OBJECTIVE: To examine the characteristics of elementary school children aged five to 13 years with acceptable and poor levels of asthma control.

METHODS: The present cross-sectional study of children with asthma used five indicators of control, as outlined by the Canadian Asthma Consensus Report, to categorize acceptable and poor asthma control. RESULTS: Of 153 children, 115 (75\%) were rated as having poorly controlled asthma. Of those with poor control, 65 (64\%) children were currently using inhaled corticosteroids, and $65 \%$ of those reported using inhaled corticosteroids daily versus as needed. Fifty-one per cent of the children with poorly controlled asthma had exposure to tobacco smoke, whereas $79 \%$ of the children with asthma under acceptable control were from households with no smokers $(\mathrm{P}=0.002)$. The poor control group also had significantly worse parental perceptions of the psychosocial impact of asthma on their child. No significant difference was found in the percentage of those who had written action plans in the poor control group (28\%) compared with the acceptable control group (26\%), and similar percentages in each group stated that they used the plans.

CONCLUSIONS: Despite the high use of inhaled corticosteroids, the majority of children had poorly controlled asthma. The poor control group had more exposure to tobacco smoke and a worse psychosocial impact due to asthma. Few children had past asthma education and action plans, suggesting that there is a need to improve access to and tools for education.

Key Words: Action plans; Asthma control; Asthma management; Childhood asthma; Environmental tobacco exposure; Inhaled corticosteroids

In the past 15 years, there has been an increase in the prevalence of asthma among children in Canada and other westernized countries (1). Despite increased knowledge of disease mechanisms and the availability of improved therapies, asthma control is not optimal $(2,3)$. Although recommendations for optimal management have been defined to help provide effective control of asthma $(4,5)$, the present study, as well as previous studies, suggest that shortcomings exist in control (2) and

\section{Des facteurs associés à un mauvais contrôle de l'asthme chez des enfants de cinq à 13 ans}

HISTORIQUE : La plupart des enfants asthmatiques devraient pouvoir réussir à contrôler leur maladie de manière satisfaisante. Cependant, existe-t-il des différences entre les enfants bien contrôlés et mal contrôlés et, dans l'affirmative, comment les démarches de soins peuvent-elles être modifiées en conséquence?

OBJECTIF : Examiner les caractéristiques d'enfants de cinq à 13 ans venus d'écoles primaires et présentant un taux acceptable ou insatisfaisant de contrôle de l'asthme.

MÉTHODOLOGIE : La présente étude transversale d'enfants asthmatiques faisait appel à cinq indicateurs de contrôle exposés dans le Consensus canadien sur l'asthme, afin de classer le contrôle acceptable et le contrôle insatisfaisant de l'asthme.

RÉSULTATS : Sur 153 enfants, 115 (75\%) étaient classés comme ayant un asthme mal contrôlé. Parmi les cas mal contrôlés, 65 (64 \%) enfants prenaient des corticoïdes par aérosol, et $65 \%$ des enfants ainsi traités en prenaient tous les jours plutôt qu'au besoin. Cinquante et un pour cent des enfants atteints d'un asthme mal contrôlé étaient exposés à la fumée de cigarette, tandis que $79 \%$ des enfants asthmatiques profitant d'un contrôle acceptable provenaient de familles non fumeuses $(\mathrm{P}=0,002)$. De plus, les parents du groupe mal contrôlé avaient une perception considérablement plus négative des répercussions psychosociales de l'asthme sur leur enfant. On n'a découvert aucune différence significative du pourcentage de ceux qui possédaient un plan d'action écrit au sein du groupe mal contrôlé ( $28 \%$ ) par rapport au groupe profitant d'un contrôle acceptable ( $26 \%$ ), et un pourcentage similaire de chaque groupe affirmait utiliser leur plan.

CONCLUSIONS : Malgré la forte utilisation de corticoïdes par aérosol, l'asthme de la majorité des enfants était mal contrôlé. Le groupe mal contrôlé était plus exposé à la fumée de cigarette et souffrait de répercussions psychosociales plus négatives de l'asthme. Peu d'enfants avaient déjà reçu de l'éducation et un plan d'action sur l'asthme, ce qui indique un besoin d'améliorer l'accès à l'éducation et les outils d'éducation.

the dissemination of effective educational methods among patients, caregivers and health care providers $(6,7)$.

The Canadian Asthma Consensus Report (4) defines controlled asthma as daytime symptoms less than four times a week, night-time symptoms less than once a week, normal physical activity, mild and infrequent exacerbations, no absence from work or school, the need for less than four doses per week of short-acting beta-2 $\left(\beta_{2}\right)$-agonist, forced expiratory volume in

${ }^{1}$ Alberta Asthma Centre; ${ }^{2}$ Faculty of Nursing, University of Alberta; ${ }^{3}$ Grey Nuns Hospital, Capital Health Region; ${ }^{4}$ Faculty of Medicine and Dentistry, University of Alberta; ${ }^{5}$ Division of Pulmonary Medicine, Department of Medicine, Faculty of Medicine and Dentistry, University of Alberta; ${ }^{6}$ Department of Public Health Sciences, Faculty of Medicine and Dentistry, University of Alberta, Edmonton, Alberta; ${ }^{7}$ EpiLung Consulting, Palatine, Illinois, USA; ${ }^{8}$ AstraZeneca Canada Inc, Chair in Asthma Research, Edmonton, Alberta

Correspondence: Ms Shawna L McGhan, Alberta Asthma Centre, University of Alberta, 11402 University Avenue, Edmonton, Alberta T6G 2J3. Telephone 780-407-3178, fax 780-407-3608, e-mail smcghan@ualberta.ca 
TABLE 1

Questions and ratings used to assess level of asthma control

\begin{tabular}{|c|c|c|c|}
\hline Indicator of control & Question & $\begin{array}{l}\text { Acceptable } \\
\text { control rating }\end{array}$ & $\begin{array}{l}\text { Poor } \\
\text { control rating }\end{array}$ \\
\hline Daytime symptoms & $\begin{array}{l}\text { In a week when your child is not having problems with his/her asthma, } \\
\text { how often does he/she have symptoms such as coughing, wheezing or } \\
\text { chest tightness? }\end{array}$ & $\begin{array}{l}\text { Not at all, } \\
1 \text { to } 3 \text { times/week }\end{array}$ & $\begin{array}{l}3 \text { to } 4 \text { per week, } 5 \text { or more, } \\
\text { symptoms with physical } \\
\text { activity }\end{array}$ \\
\hline Night-time symptoms & $\begin{array}{l}\text { How often in the past } 2 \text { weeks did your child wake up with asthma } \\
\text { symptoms such as coughing, wheezing or chest tightness? }\end{array}$ & $\begin{array}{l}\text { Not at all, } \\
1 \text { to } 3 \text { times }\end{array}$ & $\begin{array}{l}4 \text { to } 8 \text { times, } 9 \text { to } 11 \text { times, } \\
\text { all the time }\end{array}$ \\
\hline Activity limitation & $\begin{array}{l}\text { Is your child limited in the kind of play he/she can do because of his/her asthma? } \\
\text { Is your child limited in the amount of play because of asthma? }\end{array}$ & No & Yes \\
\hline Exacerbation & $\begin{array}{l}\text { How severe is chest tightness on a typical day this past month? } \\
\text { How severe is wheezing on a typical day this past month? } \\
\text { How severe is shortness of breath on a typical day this past month? } \\
\text { How severe is your child's cough episode on a typical day this past month? }\end{array}$ & None, mild & Moderate, marked, severe \\
\hline Emergency visits & $\begin{array}{l}\text { In the past } 12 \text { months, did your child need to go to the emergency room } \\
\text { for his/her asthma? }\end{array}$ & No & Yes \\
\hline
\end{tabular}

$1 \mathrm{~s}$ or peak expiratory flow greater than $85 \%$ of personal best, and less than $15 \%$ diurnal variation in peak expiratory flow (4). Asthma is an inflammatory disorder and the treatment of airway inflammation early in the course of disease is associated with improved clinical outcomes $(4,8,9)$. Most children with asthma should be prescribed an inhaled corticosteroid (4) coupled with self-management education, provision of a written action plan and environmental improvements.

Using the Canadian Asthma Consensus Report (4) to define appropriate control and treatment of asthma, the present study was designed to investigate the level of control in a sample of school children aged five to 13 years, and to determine if there are differences between children with acceptable and poor asthma control.

\section{METHODS}

Study design and patient recruitment

A cross-sectional study was conducted with children before participating in an asthma education program (Roaring Adventures of Puff [10]), the results of which are reported elsewhere (11). Ethics approval for the study was attained from the Community Health Ethics Review Committee of the Capital Health Authority, Edmonton, Alberta. Criteria for selection included the following: a diagnosis of asthma by a physician and 'current asthma', as reported by the parent; informed consent from the parent or guardian; the ability to speak English; and no previous participation in the Roaring Adventures of Puff program. More than 100 letters were sent through the Edmonton Public and Catholic School Boards to all elementary schools inviting them to participate. Although 24 schools enrolled, two subsequently dropped out, two had no parent reply and one circulated incomplete questionnaires; thus, 19 schools were enrolled in the study. A letter and enrollment form were sent through the school via all students (approximately 4965 students) to parents, inviting them to enroll their children with asthma in the study. Based on a conservative prevalence rate of 10\%, 497 students may have had asthma. The Parent Asthma Questionnaire was distributed through the school to the parents and mailed back to the data manager. Of the 162 parents (corresponding to approximately $33 \%$ of the eligible children who may have had a diagnosis of asthma) that enrolled their children, there were sufficient data on 153 children to assign a level of control score, and only these children were included in the analysis.

\section{Outcome measures}

Six indicators of disease control outlined by the 1999 Canadian Asthma Consensus Report were assessed; the indicators were daytime symptoms, night-time symptoms, activity limitation, exacerbation, emergency room visits and the use of short-acting $\beta_{2}$-agonists. However, the data collected on the frequency of medication use were insufficient to establish a level of control and, thus, it was dropped from the list of criteria. A scoring system for rating children as having acceptable or poor control was derived from nine questions (Table 1). A poor overall rating was given if one or more questions were rated as poorly controlled, because the child would no longer meet the criteria of acceptable control (4). An acceptable rating overall would require no poor control scores. The medication regimen of each child was acquired from the parents' recall of medications used (ie, identifying the medication and indicating whether it was used daily or as needed). Other information collected from the mail-in questionnaire included demographic information, previous asthma education, asthma symptoms, health care utilization, school absenteeism, perceptions about how asthma impacts their child, and self-management practices, including exposure to pets and cigarette smoking, and a written asthma action plan from the child's physician.

\section{Statistical analyses}

SPSS software (version 11.5, SPSS Inc, USA) was used for statistical analysis. For the analysis, in accordance with the above defined criteria, the children were categorized as having either acceptable or poor control. Statistical significance of differences between acceptable and poor control was evaluated using the Pearson $\chi^{2}$ test for categorical variables and the paired $t$ test for ordinal variables (two-tailed, $\mathrm{P}<0.05$ ). Univariate logistical regression was performed on each variable to determine which independent variable predicted level of control, and the odds ratio with a 95\% CI. Statistically significant variables $(\mathrm{P}<0.05)$, age, sex and parent-rated severity were subjected to a multivariate logistical regression analysis to control for age, sex and severity (95\% CI).

Demographics

\section{RESULTS}

The mean age of the children was 8.8 years, ranging from five to 13 years (Table 2 ). The majority were boys (59\%), had parents with postsecondary education $(62 \%$ of mothers and 
TABLE 2

Demographics of children with an acceptable or poor level of asthma control

\begin{tabular}{lcc}
\hline & $\begin{array}{c}\text { Acceptable } \\
(\mathbf{n = 3 8 )}\end{array}$ & $\begin{array}{c}\text { Poor } \\
(\mathbf{n = 1 1 5})\end{array}$ \\
\hline $\begin{array}{l}\text { Age, mean years } \pm \text { SD } \\
\text { Sex, \% }\end{array}$ & $9.0 \pm 1.52$ & $8.7 \pm 1.78$ \\
Boys & 57.9 & 59.1 \\
Girls & 42.1 & 40.9 \\
Mother's education, \% & & \\
Less than grade 12 & 31.3 & 39.1 \\
Postsecondary & 68.8 & 60.9 \\
Father's education, \% & & 29.8 \\
Less than grade 12 & 29.0 & 70.2 \\
Postsecondary & 71.0 & \\
Ethnic background, \% & & 79.1 \\
Caucasian & 76.3 & 20.9 \\
Non-Caucasian & 23.7 & \\
Any past special & & 54.0 \\
asthma education, \% & & 56.5 \\
$\quad$ No & 50.0 & \\
Yes & 50.0 & \\
When asthma education & & \\
occurred, \% & & \\
$\quad$ Less than 4 years ago & & \\
More than 4 years ago & & \\
\hline & & \\
\hline
\end{tabular}

$70 \%$ of fathers) and were Caucasian (78\%). Approximately two-thirds $(64 \%)$ of the children were rated by their parents as having mild asthma, which was described as infrequent interference with normal lifestyle. Less than one-half (43\%) stated that they had received any 'special asthma education' in the past, and greater than one-half (55\%) of those received it more than four years ago. No significant difference was found in demographics, including differences in height, weight and age of diagnosis between the acceptable and poor control groups.

\section{Asthma control}

Of the 153 eligible respondents, 115 (75\%) children had poor asthma control, whereas 38 (25\%) children had acceptable control. The most commonly cited indicator of poor control was limitation in the amount or kind of play because of asthma symptoms (67\%). Exacerbations (52\%) and daytime asthma symptoms (49\%) were also commonly reported indicators. Of those in the poor control group, $26 \%$ visited the emergency department an average of 1.8 times in the past year due to asthma. Sixty-eight per cent of poorly controlled participants had unscheduled physician visits (mean 3.1 visits) in the past year, but this was not significantly different from those with acceptable control (61\%, mean 2.2 visits) ( $\mathrm{P}=0.056$ for mean visits). Significantly more children with poorly controlled asthma $(81.4 \%)$ missed one or more school days due to asthma (mean 6.5 days) in the past school year compared with those with acceptable control $(53 \%$, mean 3.1 days $)(\mathrm{P}<0.05)$. Children who missed any school days due to asthma were 3.8 times (95\% CI 1.55 to 9.41) more likely to have poor asthma control.

Inhaled corticosteroid and $\beta_{2}$-agonist use

Data on medication use were available for 136 of 153 children (Table 3). Eighty-three (62\%) of these children used inhaled
TABLE 3

Use of medication in children with an acceptable or poor level of asthma control

\begin{tabular}{lccc}
\hline & $\begin{array}{c}\text { Acceptable } \\
(\%)\end{array}$ & $\begin{array}{c}\text { Poor } \\
(\%)\end{array}$ & P \\
\hline Uses inhaled corticosteroid $\left(n=135^{*}\right)$ & 54.5 & 63.7 & \\
Daily use of inhaled corticosteroid $\left(\mathrm{n}=83^{*}\right)$ & 38.9 & 64.6 & 0.05 \\
Uses beta-2-agonist $(\mathrm{n}=153)$ & 71.1 & 80.9 & \\
Daily use of beta-2-agonist $\left(\mathrm{n}=121^{*}\right)$ & 0.0 & 18.3 & 0.015 \\
Current oral steroid use $(\mathrm{n}=153)$ & 0.0 & 6.1 & \\
\hline
\end{tabular}

${ }^{*} n$ does not equal 153 due to missing variable responses or because the response was based on a positive response from previous question(s)

TABLE 4

Self-management practices of children with an acceptable or poor level of asthma control

\begin{tabular}{lccc}
\hline & $\begin{array}{c}\text { Acceptable } \\
(\%)\end{array}$ & $\begin{array}{c}\text { Poor } \\
(\%)\end{array}$ & P \\
\hline Provided a written action plan $\left(n=148^{*}\right)$ & 26.3 & 28.2 & \\
Used written action plan $\left(n=39^{\star}\right)$ & 100.0 & 93.3 & \\
Used peak flow meter $(n=153)$ & 47.4 & 39.1 & \\
Any cigarette smoke in the home $(n=153)$ & 21.1 & 51.3 & 0.001 \\
Tries to avoid triggers $\left(n=146^{\star}\right)$ & 70.3 & 85.3 & 0.042
\end{tabular}

${ }^{*} n$ does not equal 153 due to missing variable responses or because the response was based on a positive response from previous question(s)

corticosteroids. No significant difference was found between the use of inhaled steroids in the acceptable control group $(55 \%)$ and the poor control group (64\%). For children with poorly controlled asthma using inhaled corticosteroids, the majority reported 'daily use' (65\%) as opposed to 'as needed' dosing (35\%). Interestingly, the reverse was true for the acceptable control group, with $61 \%$ using inhaled corticosteroids as needed ( $\mathrm{P}=0.05$ versus poor control group). Inhaled corticosteroids were used by 42 of $59(71 \%)$ children with prior asthma education and 41 of 77 (53\%) children without prior asthma education (OR 2.17, 95\% CI 1.06 to 4.45).

Ninety-three (81\%) children currently used $\beta_{2}$-agonists in the poor control group compared with $71 \%$ in the acceptable control group $(\mathrm{P}=0.2)$. Data collected on the frequency of $\beta_{2}$-agonist use was difficult to interpret because the responses contained insufficient information. In the poor control group, $17(18 \%)$ children reported regular daily use of $\beta_{2}$-agonists and seven $(6 \%)$ children were currently using oral steroids.

\section{Self-management practices}

Forty-one (28\%) children reported receiving an action plan designed to guide treatment for symptomatic asthma (Table 4). Among those in the poor control group, $31(28 \%)$ children had an action plan and 29 (93\%) reported using it. These percentages did not significantly differ from those in the acceptable control group (26\% had an action plan and 100\% used it). Of the children without action plans, 52\% (50 of 95 children) used inhaled corticosteroids, whereas of those with action plans, $81 \%$ (30 of 37) used inhaled corticosteroids (OR 3.86, 95\% CI 1.54 to 9.64). Interestingly, significantly more parents in the poor control group reported that their child tried to avoid triggers some to most of the time (85\%) compared with the acceptable control group ( $70 \%, \mathrm{P}=0.04)$. 
TABLE 5

Odds ratios on significant variables for poor asthma control after multivariate analysis

\begin{tabular}{lcccc}
\hline Variable & OR & Lower & Upper & $\mathbf{P}$ \\
\hline Age & 0.92 & 0.68 & 1.26 & 0.61 \\
Sex & 0.81 & 0.31 & 2.10 & 0.67 \\
Parent-rated severity & 6.30 & 1.10 & 35.99 & 0.04 \\
School absenteeism & 1.63 & 0.57 & 4.67 & 0.37 \\
Avoids triggers & 1.82 & 0.59 & 5.62 & 0.30 \\
Confident in daily management & 0.68 & 0.41 & 1.14 & 0.14 \\
Fears death & 1.16 & 0.70 & 1.91 & 0.56 \\
Any smoke in home & 3.14 & 1.09 & 9.06 & 0.03 \\
Interferes with social life & 1.17 & 0.54 & 2.56 & 0.69 \\
Interferes with school performance & 1.60 & 0.72 & 3.52 & 0.25 \\
\hline
\end{tabular}

A 95\% Cl was used. An OR of 1.0 or greater equals poor control

Exposure to smoking in the household

Sixty-seven (44\%) households reported having smoke exposure in the home. Fifty-nine (51\%) of the children in households with smokers (occasional and regular) were in the poor asthma control group compared with eight $(21 \%)$ in the acceptable control group $(\mathrm{P}<0.001)$ (Table 4). Children exposed to cigarette smoke were 4.0 times (95\% CI 1.67 to 9.35) more likely to have poor control. Each hour of smoke exposure per week increased the risk of having poor control by 33\% (OR $1.33,95 \%$ CI 1.02 to 1.74 ). Using a multivariate logistical regression analysis of all significant variables, the only variable that remained a significant predictor of poor control was cigarette smoke exposure (Table 5). Of those taking inhaled corticosteroids, a significantly higher percentage were from nonsmoking homes ( $65 \%$ [54 of 83 children], $\mathrm{P}=0.021$ ).

\section{Psychosocial impact}

Children with poorly controlled asthma had significantly worse mean parental perception scores on a scale of one (strongly disagree) to five (strongly agree) (Table 6). The poor control group scored significantly worse than the acceptable control group on the child's confidence level in daily asthma management ( 3.6 versus $4.1, \mathrm{P}=0.009$ ), interference with social life ( 2.3 versus $1.5, \mathrm{P}<0.001$ ), interference with school performance ( 2.4 versus $1.4, \mathrm{P}<0.001$ ), active participation in sports (3.7 versus $4.2, P=0.01$ ) and fears that asthma may cause death $(2.0$ versus $1.6, \mathrm{P}<0.05)$.

\section{DISCUSSION}

\section{Asthma control}

The symptoms of asthma can be managed, and progression of the disease can be controlled as outlined in current practice guidelines $(4,12,13)$. However, asthma control is a challenge in many westernized countries $(14,15)$. There is inadequate dissemination of and adherence to clinical guidelines among primary care physicians $(16,17)$, and there is a lack of application of self-management strategies among patients (18-20). Thus, disparity exists between what is currently recommended about the treatment of asthma and what occurs in practice in the community and at home. The present study was undertaken to examine the level of asthma control in elementary school children in Edmonton, Alberta, and to investigate characteristics of children with an acceptable or a poor level of asthma control.
TABLE 6

\begin{tabular}{|c|c|c|c|c|}
\hline Level of control & $\mathbf{n}^{*}$ & Mean & SD & $\mathbf{P}$ \\
\hline \multicolumn{5}{|c|}{ Child confident in daily management } \\
\hline Acceptable & 35 & 4.1 & 0.93 & 0.009 \\
\hline Poor & 108 & 3.6 & 1.12 & \\
\hline \multicolumn{5}{|c|}{ Interferes with child's social life } \\
\hline Acceptable & 36 & 1.5 & 0.84 & $\leq 0.0001$ \\
\hline Poor & 108 & 2.3 & 1.24 & \\
\hline \multicolumn{5}{|c|}{ Interferes with child's school performance } \\
\hline Acceptable & 36 & 1.4 & 0.69 & $\leq 0.0001$ \\
\hline Poor & 108 & 2.4 & 1.34 & \\
\hline \multicolumn{5}{|c|}{ Feels different from other children } \\
\hline Acceptable & 36 & 1.6 & 1.05 & 0.09 \\
\hline Poor & 106 & 2.0 & 1.21 & \\
\hline \multicolumn{5}{|c|}{ More successful if did not have asthma } \\
\hline Acceptable & 36 & 1.6 & 1.10 & 0.17 \\
\hline Poor & 104 & 2.0 & 1.32 & \\
\hline \multicolumn{5}{|c|}{ Actively participates in sports } \\
\hline Acceptable & 36 & 4.2 & 1.05 & 0.01 \\
\hline Poor & 107 & 3.7 & 1.27 & \\
\hline \multicolumn{5}{|c|}{ Concerned about teasing } \\
\hline Acceptable & 35 & 2.1 & 1.41 & 0.38 \\
\hline Poor & 108 & 2.4 & 1.52 & \\
\hline \multicolumn{5}{|c|}{ Fears asthma could cause death } \\
\hline Acceptable & 36 & 1.6 & 0.97 & 0.022 \\
\hline Poor & 106 & 2.0 & 1.33 & \\
\hline
\end{tabular}

Ratings are on a scale of one (strongly disagree) to five (strongly agree). ${ }^{*} n$ does not equal 153 due to missing variable responses or because the response was based on a positive response from previous question(s)

Our results showed that the majority of children (75\%) with asthma aged five to 13 years were poorly controlled, as defined by the 1999 Canadian Asthma Consensus Report (4). Poor asthma control was defined as one or more poor control scores for any of the five indicators of asthma control. These data are comparable with another Canadian study (16) in which $76 \%$ of 1001 patients failed to meet one or more of six control criteria (1996 guidelines). In Europe, 49\% of 572 Swiss-German children with wheezing had unsatisfactory control, with sleep disturbances, restricted activities and school absenteeism (21).

Exercise limitation due to asthma was a major contributor to the overall rating of poor control, and other studies show comparable results. Chapman et al (16) found that the most commonly cited control criteria were daytime symptoms, limitations in physical activity and sleep disturbances. A study of 1788 patients with asthma in the United States (22) found that of those with moderate persistent asthma, $63.8 \%$ had a physical function impact. Thus, activity limitation is an important component in the assessment of the level of asthma control, and also indicates a critical need for educational intervention.

\section{Medication use}

Although many of the children in our study had poorly controlled asthma, the majority of children (61\%) reported using inhaled corticosteroids. A chart review of community-based general practitioners found an even higher use of inhaled corticosteroids (68\%) in the same population region (23). By contrast, recent large multinational surveys have found a low use of preventive treatments in patients with intermittent to severe 
asthma, including $10 \%$ to $20 \%$ in the United States, $18 \%$ to $26 \%$ in western Europe and 7\% to 11\% in Japan (14). In Sweden, however, there is a higher use of inhaled steroids, ranging from $28.6 \%$ for mild intermittent asthma to $83.3 \%$ for severe persistent asthma (24). In our poor control group, the daily use of inhaled corticosteroids was reported for $42(65 \%)$ children. Studies of inhaled corticosteroids suggest that they should be used as firstline regular maintenance therapy because they significantly lower the risk of fatal or near-fatal asthma (25), significantly improve asthma control (26) and improve forced expiratory volume in $1 \mathrm{~s}$, along with the fact that early treatment may prevent development of irreversible airway obstruction (9).

It is surprising that despite the high use of inhaled corticosteroids in the present study, the level of asthma control was not significantly different. Similar international findings showed that more severe symptoms were not associated with an increased use of preventive medication (14,24). In fact, Cowie et al (27) noted the same phenomena in their large cross-sectional study, finding that only $15 \%$ of 2437 subjects using inhaled corticosteroids achieved asthma control. It is possible that differences in severity among those with poor asthma control had an impact on the level of improvement seen with inhaled steroid use; however, researchers have suggested that asthma control is achievable for most patients (27-29). Many factors have an impact on the benefit that a patient receives from asthma medication. For example, we do not know how the children used their inhalers and whether they received training on proper use; the improper use of inhaled devices in children, adults and medical personnel is well documented (30-32). It is possible that many parents and children were not adequately educated on the rationale for using, how and when to use, and the side effects of and the potential effects of not using an inhaled antiinflammatory therapy, thus causing erratic or discontinued use. Interestingly, a significant improvement was found in those receiving inhaled anti-inflammatory therapy with prior asthma education, regardless of when education occurred and whether they had an action plan. For various, often well-intended reasons, parents often do not follow prescribed medication regimens $(19,33,34)$. Assessment and education about medication use, frequency and technique are vital.

Unscheduled physician visits were the only control indicator that was not significantly different between acceptable (61\%) and poor control $(68 \%)$. This finding suggests that those with acceptable control are proactive in managing their asthma by responding to problems before they become an emergency. Greater access to personalized written action plans may reduce the need for unscheduled physician visits (35).

\section{Management practices}

Our data suggest that patients will use a written action plan if provided by their physician. Among those with poor control, 28\% had been given a written action plan and 93\% reported using it. However, perhaps because of the low number who had an action plan, no difference in the level of control was seen in children with and without action plans. Significantly better inhaled steroid use was found among action plan users, suggesting that patients who are encouraged to use an action plan manage their asthma better. One question worth further exploring is whether a commonality existed among action plan users (ie, the type of action plan provided and whether it was subsequently used and effective). A review of 3000 asthma patient charts in the same region as this study found that only $2 \%$ of general practitioners documented provision of an action plan (23). Considering the difference between the portion of physicians that do not document and the number of families that indicated they had an action plan, it is not clear whether the families in the present study are representative of the general population of families with asthma or whether the provision of action plans is not well documented. A meta-analysis (35) of randomized controlled trials showed that written action plans are associated with improved asthma outcomes. Furthermore, a recent case-control study (36) of asthma mortality showed that an action plan was a major protective factor against death from asthma. The number of action plans provided to subjects in our study was much lower than in other parts of the world such as France $(49 \%)$, Spain (60.5\%) (24) and Brazil (43\% to 69\% of emergency department users) (37). A coordinated approach to increase the provision of action plans among clinicians is needed. The action steps should indicate when and what to do when the level of asthma control is acceptable, poor or needing medical attention.

\section{Asthma education}

Asthma education and clinician-generated action plans are important for achieving acceptable asthma control, as identified in the practice guidelines $(4,12,13)$. However, in the present study, prior asthma education, as defined by the parent, did not significantly differ between groups. Of the 59 children who reported receiving asthma education at any time in the past, $70 \%$ were poorly controlled. This finding may reflect a lack of effectiveness of the education or a loss of effect since completion. It is well known that regular reinforcement is needed for asthma education to be effective (38). Overall, only $43 \%$ of the parents reported any past asthma education. This identifies that there is limited availability of fundamental health care for those with asthma, namely, asthma education. Clinicians and administrators need to ensure adequate access and appropriate evidence-based delivery of asthma education (39) for, at the very least, those families who have poorly controlled asthma. Interestingly, only 10 (15\%) parents of those who had received asthma education had received it in the past four years.

\section{Environmental tobacco smoke exposure}

Household cigarette smoke exposure was the single most significant factor in predicting poor control. This is comparable with other studies that found that children exposed to tobacco smoke were more likely to have moderate to severe asthma than those with mild intermittent asthma (22), as well as increased asthma exacerbations, symptoms and negative effects on lung function $(40,41)$. Smoking is also a factor in poor program attendance or poor educational impact $(42,43)$. In our study, $67(44 \%)$ children lived in households with regular or occasional smoke exposure, and asthma control in these households was significantly worse than in nonsmoking households $(51 \%$ of poor control versus $21 \%$ of acceptable control, $\mathrm{P}=0.005)$. In fact, each hour per week of smoke exposure increased the likelihood of poor control by 33\%. Therefore, reducing exposure should be a high priority for clinicians and health providers. In addition, despite the use of inhaled corticosteroids in 19 of the children with smoke exposure, none achieved acceptable control. Avoidance of smoke exposure should be a relatively simple management strategy (eg, parents smoke only outside). However, researchers acknowledge that smoking is riddled with emotional and behavioural complexities $(42,44,45)$ that clinicians often ignore. All parents of children with asthma should be 
coached to smoke outside the home only, if cessation is not immediately achievable. A program designed to coach parents on reducing tobacco smoke exposure for their children with asthma combined with an asthma management program was successful in reducing cotinine levels (44). Collaboration with action-on-smoking groups is essential to improve the reduction of smoke exposure in the children of those who smoke.

\section{Psychosocial impact}

Growing interest exists in the role of psychosocial and quality of life indicators in asthma management $(39,46)$. We found that children in the poor control group had significantly worse ratings on feelings such as confidence in managing asthma and fear of dying, as well as impact on quality of life from interference with social activities, school performance, sporting activities and school attendance. Studies have shown that negative psychosocial factors can interfere with a family's coping skills (47), as well as the ability to manage asthma and appropriately perceive symptoms (48), and can also result in higher emergency department utilization (46). Further investigations are needed to explore psychosocial factors that impact the level of control. These factors must be assessed and appropriate education provided to improve patient self-management skills and the quality of life for the patients and their caregivers.

\section{Limitations}

Our study had limitations that affect its interpretation. First, we used an aggressive measure of control, namely, no evidence of unacceptable control. Although this criterion is consistent with the 1999 Canadian consensus guidelines, it depends on subjective evaluation of what is considered acceptable control to each patient. Second, our questions have limitations. We did not include unscheduled physician visits as a control criterion because it was difficult to establish the reason for the visit

\section{REFERENCES}

1. Weiland SK, Husing A, Strachan DP, Rzehak P, Pearce N; ISAAC Phase One Study Group. Climate and the prevalence of symptoms of asthma, allergic rhinitis, and atopic eczema in children.

Occup Environ Med 2004;61:609-15.

2. Mo F, Robinson C, Choi BC, Li FC. Childhood asthma management and control. Analysis of the Student Lung Health Survey (SLHS) database, Canada 1996. Int J Adolesc Med Health 2004;16:29-40.

3. Lava J, Moore R, Li F, El-Saadany S. Childhood Asthma in Sentinel Health Units: Report of the Student Lung Health Survey Results 1995-1996. Ottawa: Health Canada, 1998.

4. Boulet LP, Becker A, Berube D, Beveridge R, Ernst P. Canadian Asthma Consensus Report, 1999. Canadian Asthma Consensus Group. CMAJ 1999;161(Suppl 11):S1-61.

5. Boulet LP, Bai TR, Becker A, et al. What is new since the last (1999) Canadian Asthma Consensus Guidelines? Can Respir J 2001;8(Suppl A):5A-27A.

6. Boulet LP, Phillips R, O'Byrne P, Becker A. Evaluation of asthma control by physicians and patients: Comparison with current guidelines. Can Respir J 2002;9:417-23.

7. Jin R, Choi BC, Chan BT, et al. Physician asthma management practices in Canada. Can Respir J 2000;7:456-65.

8. Selroos O, Lofroos AB, Pietinalho A, Riska H. Asthma control and steroid doses 5 years after early or delayed introduction of inhaled corticosteroids in asthma: A real-life study. Respir Med 2004;98:254-62.

9. Haahtela T, Jarvinen M, Kava T, et al. Effects of reducing or discontinuing inhaled budesonide in patients with mild asthma. N Engl J Med 1994;331:700-5.

10. McGhan SL, Wells HM, Befus AD. The "Roaring Adventures of Puff": A childhood asthma education program. J Pediatr Health Care 1998;12:191-5. (eg, early signs of problems or an exacerbation). In addition, we did not include medication use in the control criteria because of incomplete data. For example, many parents reported that they used $\beta_{2}$-agonists as needed, but did not specify how often it was used. In addition, parental reports of medication use do not necessarily reflect actual use. The present study did not examine all potential quality of life domains using a validated tool, but focused only on the parental perceptions of how asthma impacted their child. Additionally, although schools were randomly selected, it is possible that because our study used patients who participated on a voluntarily basis, a 'selection bias' may have existed, which contributed to the higher levels of poor control we observed.

\section{CONCLUSIONS}

Despite a high prevalence of inhaled corticosteroid use (62\%), the majority of children in our study had poorly controlled asthma (75\%) according to the Canadian guidelines. This finding could be due, in part, to cigarette smoke exposure (a major factor of poor control), an inadequate availability of asthma education and action plans, and psychosocial factors. Further investigation is needed to understand why a high percentage of children using inhaled corticosteroids are poorly controlled.

ACKNOWLEDGEMENTS: We would like to thank the participating parents and children. Thank you to the principals, schools and Public and Catholic School Boards for facilitating access to the students with asthma. Thank you to Dr A Senthilselvan, Department of Public Health Sciences, University of Alberta, for his statistical support.

FUNDING: This study was funded by the Alberta Asthma Network of the Alberta Lung Association.

11. McGhan SL, Wong E, Jhangri GS, et al. Evaluation of an education program for elementary school children with asthma. J Asthma 2003;40:523-33.

12. British Thoracic Society; Scottish Intercollegiate Guidelines Network. British guideline on the management of asthma. Thorax 2003;58(Suppl 1):i1-94.

13. National Asthma Education and Prevention Program. National Asthma Education and Prevention Program. Expert Panel Report: Guidelines for the Diagnosis and Management of Asthma Update on Selected Topics - 2002. J Allergy Clin Immunol 2002;110:S141-S219. (Erratum in 2003;111:466).

14. Rabe KF, Adachi M, Lai CK, et al. Worldwide severity and control of asthma in children and adults: The global asthma insights and reality surveys. J Allergy Clin Immunol 2004;114:40-7.

15. Laforest L, Yin D, Kocevar VS, et al. Association between asthma control in children and loss of workdays by caregivers. Ann Allergy Asthma Immunol 2004;93:265-71.

16. Chapman KR, Ernst P, Grenville A, Dewland P, Zimmerman S. Control of asthma in Canada: Failure to achieve guideline targets. Can Respir J 2001;8(Suppl A):35A-40A.

17. Meng YY, Leung KM, Berkbigler D, Halbert RJ, Legorreta AP. Compliance with US asthma management guidelines and specialty care: A regional variation or national concern? J Eval Clin Pract 1999;5:213-21.

18. Barr RG, Somers SC, Speizer FE, Camargo CA Jr; National Asthma Education and Prevention Program (NAEPP). Patient factors and medication guideline adherence among older women with asthma. Arch Intern Med 2002;162:1761-8.

19. Gibson NA, Ferguson AE, Aitchison TC, Paton JY. Compliance with inhaled asthma medication in preschool children. Thorax 1995;50:1274-9. 
20. Rand CS, Wise RA. Measuring adherence to asthma medication regimens. Am J Respir Crit Care Med 1994;149:S69-76.

21. Kuehni CE, Frey U. Age-related differences in perceived asthma control in childhood: Guidelines and reality. Eur Respir J 2002;20:880-9.

22. Fuhlbrigge AL, Adams RJ, Guilbert TW, et al. The burden of asthma in the United States: Level and distribution are dependent on interpretation of the national asthma education and prevention program guidelines. Am J Respir Crit Care Med 2002;166:1044-9.

23. Tsuyuki RT, Sin DD, Sharpe HM, Cowie RL, Nilsson C, Man SF; Alberta Strategy to Help Manage Asthma (ASTHMA) Investigators. Management of asthma among community-based primary care physicians. J Asthma 2005;42:163-7.

24. Vermeire PA, Rabe KF, Soriano JB, Maier WC. Asthma control and differences in management practices across seven European countries. Respir Med 2002;96:142-9.

25. Ernst P, Spitzer WO, Suissa S, et al. Risk of fatal and near-fatal asthma in relation to inhaled corticosteroid use. JAMA 1992;268:3462-4.

26. Pauwels RA, Yernault JC, Demedts MG, Geusens P. Safety and efficacy of fluticasone and beclomethasone in moderate to severe asthma. Belgian Multicenter Study Group. Am J Respir Crit Care Med 1998; 157:827-32.

27. Cowie RL, Underwood MF, Field SK. Inhaled corticosteroid therapy does not control asthma. Can Respir J 2004;11:555-8.

28. Cockcroft DW, Swystun VA. Asthma control versus asthma severity. J Allergy Clin Immunol 1996;98:1016-8.

29. Bateman ED, Bousquet J, Braunstein GL. Is overall asthma control being achieved? A hypothesis-generating study. Eur Respir J 2001;17:589-95.

30. Scarfone RJ, Capraro GA, Zorc JJ, Zhao H. Demonstrated use of metered-dose inhalers and peak flow meters by children and adolescents with acute asthma exacerbations. Arch Pediatr Adolesc Med 2002;156:378-83.

31. Thompson J, Irvine T, Grathwohl K, Roth B. Misuse of metered-dose inhalers in hospitalized patients. Chest 1994;105:715-7.

32. Resnick DJ, Gold RL, Lee-Wong M, Feldman BR, Ramakrishnan R, Davis WJ. Physicians' metered dose inhaler technique after a single teaching session. Ann Allergy Asthma Immunol 1996;76:145-8.

33. Bender B, Milgrom H, Rand C, Ackerson L. Psychological factors associated with medication nonadherence in asthmatic children. J Asthma 1998;35:347-53.

34. Chambers CV, Markson L, Diamond JJ, Lasch L, Berger M. Health beliefs and compliance with inhaled corticosteroids by asthmatic patients in primary care practices. Respir Med 1999;93:88-94.
35. Gibson PG, Powell H. Written action plans for asthma: An evidence-based review of the key components. Thorax 2004:59:94-9.

36. Abramson MJ, Bailey MJ, Couper FJ, et al; Victorian Asthma Mortality Study Group. Are asthma medications and management related to deaths from asthma? Am J Respir Crit Care Med 2001;163:12-8.

37. Fernandes AK, Mallmann F, Steinhorst AM, et al. Characteristics of acute asthma patients attended frequently compared with those attended only occasionally in an emergency department. J Asthma 2003;40:683-90.

38. Ignacio-Garcia JM, Pinto-Tenorio M, Chocron-Giraldez MJ, et al. Benefits at $3 \mathrm{yrs}$ of an asthma education programme coupled with regular reinforcement. Eur Respir J 2002;20:1095-101.

39. McGhan SL, Cicutto LC, Befus AD. Advances in development and evaluation of asthma education programs. Curr Opin Pulm Med 2005;11:61-8.

40. Burr ML, Anderson HR, Austin JB, et al. Respiratory symptoms and home environment in children: A national survey. Thorax 1999;54:27-32. (Erratum in 1999;54:376).

41. Morkjaroenpong V, Rand CS, Butz AM, et al. Environmental tobacco smoke exposure and nocturnal symptoms among inner-city children with asthma. J Allergy Clin Immunol 2002;110:147-53.

42. Fish L, Wilson SR, Latini DM, Starr NJ. An education program for parents of children with asthma: Differences in attendance between smoking and nonsmoking parents. Am J Public Health 1996;86:246-8.

43. Gallefoss F, Bakke PS. Does smoking affect the outcome of patient education and self-management in asthmatics? Patient Educ Couns 2003;49:91-7.

44. Hovell MF, Meltzer SB, Wahlgren DR, et al. Asthma management and environmental tobacco smoke exposure reduction in Latino children: A controlled trial. Pediatrics 2002;110:946-56.

45. Wakefield M, Ruffin R, Campbell D, Roberts L, Wilson D. Smoking-related beliefs and behaviour among adults with asthma in a representative population sample. Aust N Z J Med $1995 ; 25: 12-7$

46. Magid DJ, Houry D, Ellis J, Lyons E, Rumsfeld JS. Health-related quality of life predicts emergency department utilization for patients with asthma. Ann Emerg Med 2004:43:551-7.

47. Adams RJ, Wilson D, Smith BJ, Ruffin RE. Impact of coping and socioeconomic factors on quality of life in adults with asthma. Respirology 2004;9:87-95.

48. Kolbe J. Asthma education, action plans, psychosocial issues and adherence. Can Respir J 1999;6:273-80. 


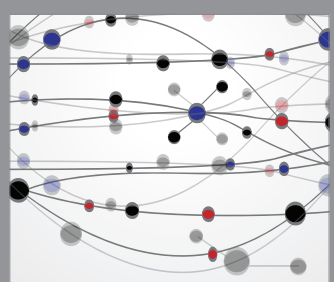

The Scientific World Journal
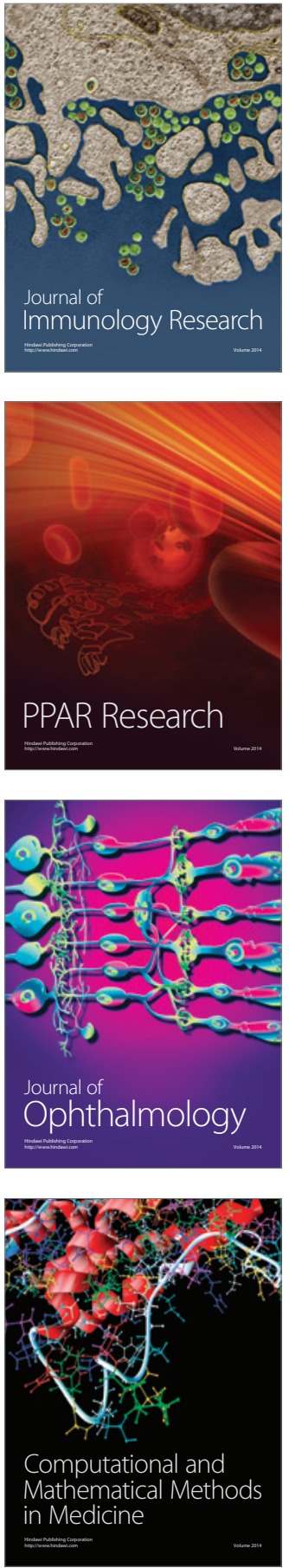

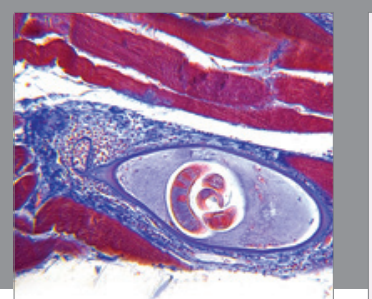

Gastroenterology Research and Practice

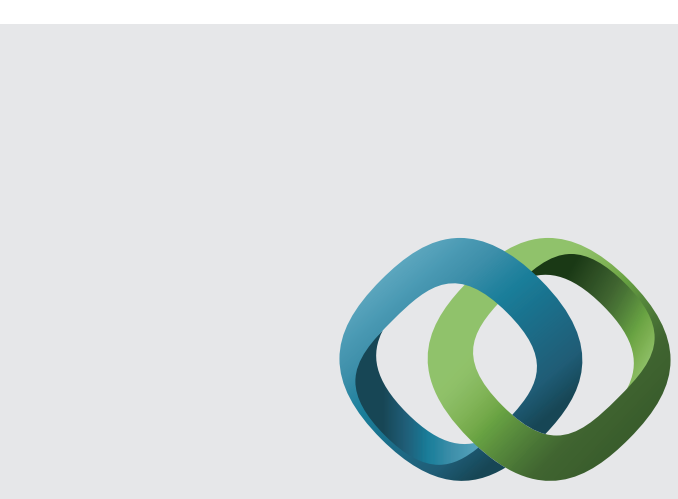

\section{Hindawi}

Submit your manuscripts at

http://www.hindawi.com
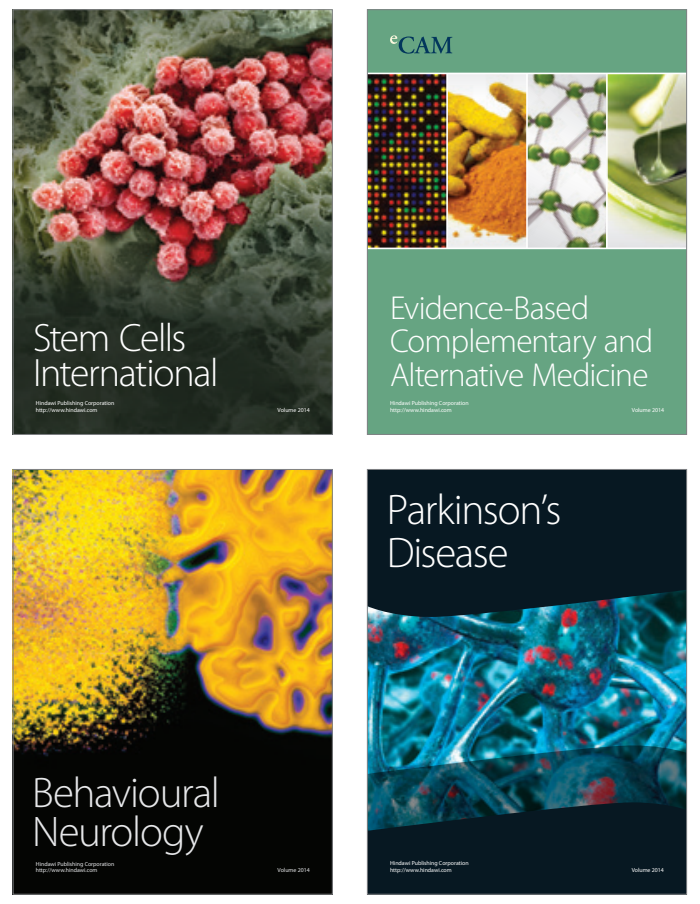
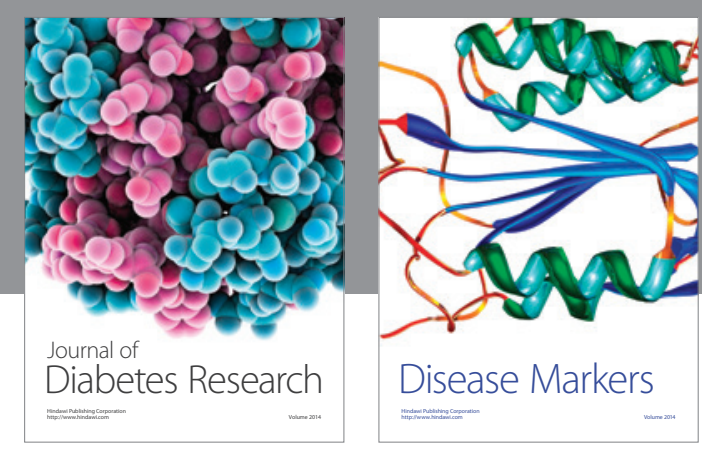

Disease Markers
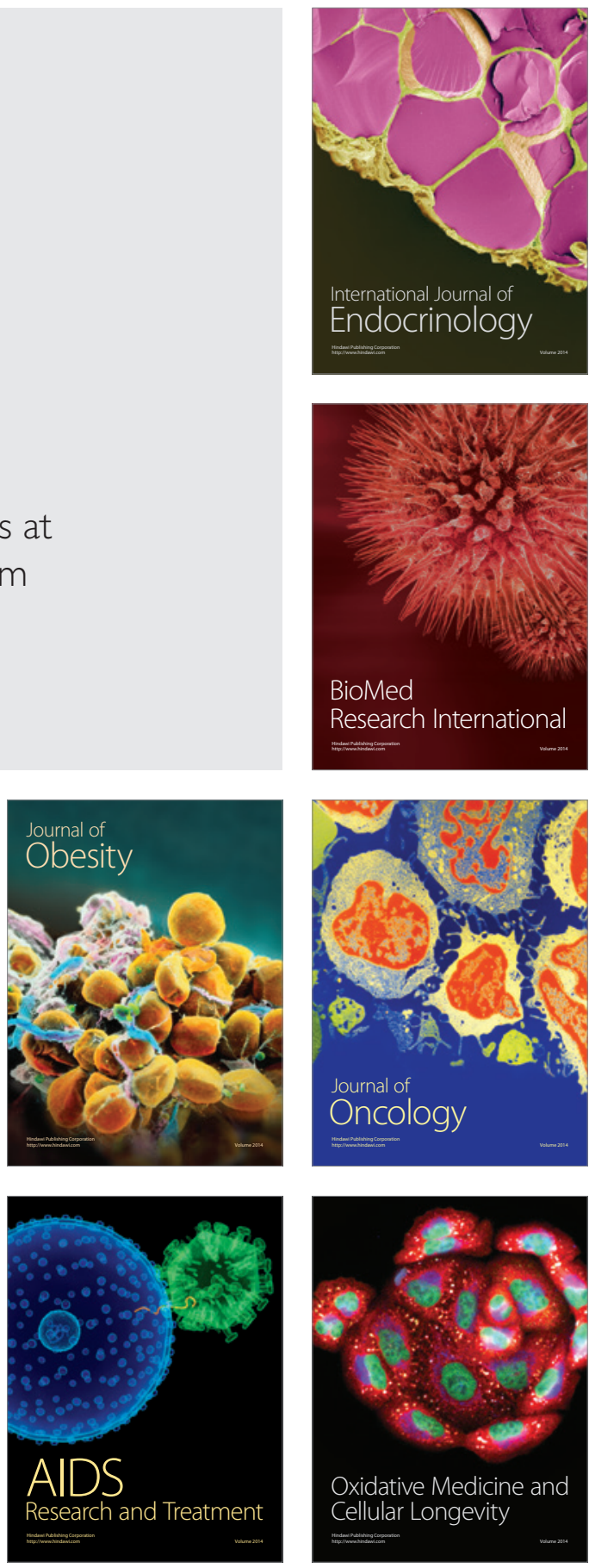